\title{
10 health stories that mattered: Nov. 10-14
}

- The Conservative government moved to limit the power of the chief public health officer. The role of deputy head of the Public Health Agency of Canada, including control of its \$615-million budget and 2500 employees, would be transferred to a president.

- The College of Family Physicians of Canada released a roadmap for developing a national home-care strategy at its annual meeting in Quebec City. The college also called on the federal government to eliminate child poverty by 2020 , and ban junk food advertising directed at children.

- Two Toronto hospitals, Sunnybrook Health Sciences Centre and Toronto East General, live-blogged colon and prostate surgeries on Twitter. Sunnybrook became the first hospital in Canada to live-tweet a surgery in February.

- Ontario banned smoking at patios, playgrounds and sports fields, and tobacco sales on university and col- lege campuses. The new rules will take effect on Jan. 1, 2015.

- The Alberta Medical Association urged the province to rethink its allocation of health dollars, after a Canadian Institute for Health Information study showed Alberta will spend nearly $\$ 4700$ per capita on health care this year. That's up $2.1 \%$ from 2013 and more than any other province bedsides Newfoundland and Labrador.

- Quebec's first medical marijuana clinic opened its doors in Montréal. According to CBC News, Santé Cannabis accepts patients referred by a treating physician and follows prescribing guidelines set by the Collège des médecins du Québec.

- Health advocates, including former Canadian Medical Association president Dr. Louis Hugo Francescutti, urged Alberta to create a \$170-million foundation for preventive care. The province currently spends about $3 \%$ of its health budget to prevent injuries and chronic diseases.
- Health Canada is "carefully monitoring" the public health risk posed by laundry-detergent pods after a Pediatrics study showed that more than 17000 American children under age 6 swallowed, inhaled or squirted pod chemicals in their eyes in 2012/13.

- Nunavut's health minister ordered an independent review of how the department handled repeated misconduct by a nurse. The government knew about nearly 20 complaints over the past two years but did not remove the nurse from her position in Cape Dorset.

- The CEO and board members of Alberta's Capital Health Region spent tens of thousands of public dollars on lavish entertainment using a secretary's corporate credit card, the CBC revealed. The expenses include a $\$ 3000$ suite at a football game with $\$ 1000$ worth of food and alcohol, a $\$ 7500$ weekend for six at the luxury Jasper Park Lodge and a nearly $\$ 12000$ restaurant tab. Lauren Vogel, CMAJ

CMAJ 2015. DOI:10.1503/cmaj.109-4944 